\title{
EFFECTS OF 8-WEEK ELECTRICAL MUSCLE STIMULATION ON THE MUSCLE CONTRACTILE PROPERTIES IN ADOLESCENT GIRLS
}

\author{
Sara PREGELJ, Boštjan ŠIMUNIČ ${ }^{1,2}$ \\ ${ }^{1}$ University of Primorska, Koper, Slovenia \\ ${ }^{2}$ Science and Research Centre Koper, Institute for Kinesiology Research, Slovenia \\ Corresponding Author: \\ Boštjan ŠIMUNIČ \\ Science and Research Centre Koper, Institute for Kinesiology Research, Garibaldijeva 1, 6000 \\ Koper, Slovenia \\ Phone: +38656637700 \\ E-mail: bostjan.simunic@zrs-kp.si
}

\section{ABSTRACT}

The study aimed to determine the effect of 8-week unilateral electrical muscle stimulation (EMS) training of leg muscles: vastus lateralis, vastus medialis and biceps femoris with the same number of muscle contractions in comparison to controls. Contractile properties were monitored by measuring the maximal voluntary isometric contraction $(M V C)$ and the rate of force development in first $50 \mathrm{~ms}\left(R F D_{50}\right)$ of knee extensors and flexors and tensiomyography of stimulated muscles. In addition, we also investigated the retained effect after 8 weeks without EMS training. Nineteen healthy young female athletes aged 15 to 18 years (average $16.4 \pm .9$ years) were randomly divided in a control group $(C G ; N=8)$ and an experimental group $(E G ; N=11) . C G$ performed maximal unilateral voluntary contractions while the EG performed also EMS training of the same leg by stimulating both vasti muscles and biceps femoris. There were no changes in $C G$ after 8 weeks of maximal unilateral voluntary training; however, EG improved $M V C$ in knee extensors $(12.6 \% ; P=.085)$ and $R F D_{50}(142.1 \% ; P=.049)$ where $R F D_{50}$ retained increased also 8 weeks after EMS training $(73 \% ; P=.090)$. Tensiomyography revealed decreased amplitude $(13.2 \% ; P=.011)$ only in EG, representing higher muscle tone after 8 weeks of EMS in comparison to CG. Our findings indicate that EMS training has a positive effect on muscle contractile properties in young female athletes even after comparing to matched controls by the number of contractions.

Keywords: EMS, muscle strength, tensiomiography, rate of force development. 


\section{VPLIV 8-TEDENSKE ELEKTRO MIŠIČNE STIMULACIJE NA KONTRAKTILNE LASTNOSTI MIŠIC MLADIH ŠPORTNIC}

\section{IZVLEČEK}

Cilj študije je bil raziskati vpliv 8 - tedenskega unilateralnega EMS treninga na lastnosti $m$. vastus medialis, $m$. vastus lateralis in $m$. biceps femoris $v$ primerjavi $s$ kontrolno skupino z enakim številom mišičnih kontrakcij. Kontraktilne lastnosti mišic smo spremljali z merjenjem največje izometrične mišične silovitosti (MVC) in hitrosti prirastka sile v prvih 50 ms $\left(R F D_{50}\right)$ mišic iztegovalk in upogibalk kolena ter tenziomiografskega odziva mišic. Poleg začetnih meritev in meritev po 8 tednih nas je zanimal še zadržan učinek po 8 tednih brez EMS. Devetnajst zdravih mladih športnic, starih od 15 do 18 let (v povprečju $16.4 \pm .9$ let), smo naključno razdelili v kontrolno $(C G ; N=8)$ in eksperimentalno skupino (EG; $N=11)$. CG je izvajala enonožne maksimalne hotene kontrakcije, medtem, ko je EG izvajala tudi trening EMS iste noge s stimulacijo srednje in stranske mogočne mišice ter dvoglave stegenske mišice. Po 8 tednih vadbe nismo našli razlik v CG, medtem, ko sta se v EG povečali MVC iztegovalk kolena (12.6\%; $P=.085)$ in $R F D_{50}$ iztegovalk kolena $(142.1 \%$; $P=.049)$, ki je ostala povečana tudi 8 tednov po zaključku EMS treninga (73\%, P =.090). Tenziomiografija je pokazala na zmanjšano amplitudo le pri EG (13.2\%; P =.011), ki je po 8 tednih EMS v primerjavi $s$ $C G$ predstavljala višji mišični tonus. Slednje ugotovitve kažejo na to, da EMS pozitivno vpliva na kontraktilne lastnosti mišic mladih športnic, tudi po primerjavi s kontrolno skupino z istim številom kontrakcij.

Ključne besede: EMS, mišična silovitost, hitrost prirastka sile, tenziomiografija.

\section{INTRODUCTION}

Electrical muscle stimulation (EMS) includes involuntary muscle contractions as a response to the electrical currents produced by the electrical device and applied through electrodes on muscles (Seyri \& Maffiuletti, 2011; Đokić \& Međedović, 2013). The stimulation impulse or pulses could be applied directly on muscles or peripheral nerve (Benito-Martinez, Martinez-Amat, Lara-Sanchez, Berdejo-del-fresno, \& MartinezLopez, 2013; Enoka, 1988). Initially, EMS was used only for therapies; however, in the last two decades, there was an increment in the EMS usage for conditioning purposes (Pichon, Martin, \& Cometti,1995; Malatesta, Cattaneo, Dugnani, \& Maffiuletti, 2003; Brocherie, Babault, Cometti, Maffiuletti, \& Chatard. 2005; Babault, Cometti, Pousson, \& Chatard, 2007; Maffiuletti, et al., 2009; Deley, Cometti, Fatnassi, Paizis, \& Babault, 2011; Benito-Martinez, Sanchez-Lara, Berdejo del Fresno, \& Martinez-Lopez, 2011; Martinez-Lopez, Benito-Martinez, Hita-Contreras, Lara-Sanchez, \& Martinez-Am- 
at, 2012). Investigators reported positive improvements in isometric muscle strength (Maffiuletti, Pensini, \& Martin, 2002; Singer, 1986; Zhou, Oakman, \& Davie, 2002; Sariyildiz, Rezvani, \& Karacan, 2011), isokinetic strength ( Deley, et al., 2011; Lategan, Crafford, Suliman, \& Govender, 2014), vertical jumping height (Malatesta, et al., 2003; Babault, et al., 2007; Martinez-Lopez, Benito-Martinez, Hita-Contreras, LaraSanchez, \& Martinez-Amat, 2012), skating and sprinting speed performance (Brocherie, et al., 2005; Benito - Martinez, et al., 2011) and motor tests ( Deley, et. al., 2011; Benito - Martinez, et. al., 2011). Most of the studies were carried out on stimulating muscle quadriceps femoris (Maffiuletti, et al., 2000; Malatesta, et al., 2003; Gondin, Guette, \& Martin, 2005; Babault, et al., 2007), muscle triceps surae (Babault, et al., 2007; Malatesta, et al., 2003), while just two studies performed EMS on muscle biceps femoris (BF) (Lategan, et. al., 2014; Marqueste, et. al, 2010).

Only five studies examined the effect of EMS on adolescent athletes (MartinezLopez, et al., 2012; Benito-Martinez, et al., 2013; Benito-Martinez, et al., 2011; Malatesta, et al., 2003; Deley, et al., 2011) and just one was done on girls only (Deley, et.al., 2011). Among them, Martinez - Lopez, et. al. (2012) reported that the combination of 8 weeks of plyometric and EMS training improve squat jump height for $28 \%$, countermovement jump for $13.7 \%$ and drop jump height for $4.1 \%$. Benito-Martinez, et. al. (2013) found that the combination of 8-week EMS and plyometric training improved 30 -meters sprint time for $6.8 \%$ and the triple jump distance for $5.2 \%$ but only in a group that practiced plyometric training before the EMS was applied. Interestingly, the study of Benito-Martinez, et. al. (2011) showed that countermovement vertical jump height improved for $13.5 \%$ in a group that applied EMS before they practiced. Effects of EMS were found also after shorter exposures, where Malatesta, et. al. (2003) observed improvements in jumping mechanical power during 15 seconds of consecutive jumps $(3.8 \%)$ after only 4 weeks of EMS training. Interestingly, after ten days of follow-up the improvements in squat jump (6.5\%), counter movement jump height (5.4\%), 15-second consecutive jump height (5.3\%) and jumping mechanical power $(5.9 \%)$ were still present.

Deley, et. al. (2011) were the only ones investigating EMS effects in adolescent girls (12.4 \pm 1.2 years) and found that 6 -week combined EMS and gymnastic training improved maximal voluntary torque at three different angular velocities already after 3 weeks $\left(38.8 \pm 29.0 \%\right.$ at $-60^{\circ} \mathrm{s}^{-1}, 25.9 \pm 28.0 \%$ at $60^{\circ} \mathrm{s}^{-1}, 40.2 \pm 22.0 \%$ at $\left.240^{\circ} \mathrm{s}^{-1}\right)$ and interestingly not after 6 weeks. After 3 weeks of training, they found also improvements in squat jump height $(20.9 \pm 8.3 \%)$, reactivity test $(20.4 \pm 26.2 \%)$ and specific jump performance tests $(14.9 \pm 17.2 \%)$. Squat jump height was also improved after 6 weeks of training while other tests were not. The improvements in counter movement jump height were present only after 6 weeks of training $(10.1 \pm 10.0 \%)$. After 4 weeks of follow-up, only squat jump height remained improved. Obviously, there are discrepancies in data of the presented maximal voluntary tests that warrants more objective measures of muscle contractility improvements after EMS.

The most important physiological aspect which differs between EMS and voluntary contraction is recruitment of motor units. EMS recruit motor points randomly and non- 
selective (Gregory \& Bickel, 2005), while in voluntary contraction recruitment follows the Henneman size principle (Henneman, Somjen, \& Carpenter, 1965). This indicates that the EMS can recruit more fast motor units and we would expect increase in overall skeletal muscle contraction velocity. Although skeletal muscle contraction velocity could not be determined by dynamometry, non-invasive tensiomyography (TMG) was developed to detect mechanical properties of the skeletal muscles where contraction time alone or pooled with delay time and half-relaxation time correlates with myosin heavy chain I proportion (Šimunič et al., 2011). TMG was previously used in adults in an 8-week plyometric study, where Zubac and Šimunič (2016) demonstrated shorter contraction time of 4 (out of 5) lower limb muscles and lower TMG response amplitude in all muscles. However, TMG was not used after EMS training study.

Therefore, the aim of our study was to determine the effect of 8-week EMS training of non-dominant leg on the TMG and MVC-derived contractile properties of vastus lateralis (VL), vastus medialis (VM) and BF muscle in young female athletes. In addition, we also investigated the retained effect after 8 weeks of follow-up.

\section{METHODS}

\section{Participants}

Twenty young female athletes (average age: $16.4 \pm .9$ years, Table 1) voluntarily decided to participate in the study. The girls have practiced regularly various sports such as artistic roller skating, athletics, handball, gymnastics, dancing, cheerleading and twirling for at least last 5 years. Their sport training was carried out $3-6$ times per week, in average 5 times per week. Most of the girls competed at international level, nine of them also at European and World championships, other at national level. The study was presented to the parents and girls together with the purpose of the study and its intended course and the procedures that will be carried out in the framework of the research. The parents of the girls signed an informed-consent prior to the study. The study was approved by Institutional ethics board at Science and Research Centre Koper.

\section{Study Design}

The research lasted for almost five months and was consisted of three testings. After the familiarization in the first week, the initial testing (BDC) was carried out, followed by 8 -week interventions in both groups. The second testing (END) was performed after the interventions. Furthermore, the third testing (FU) was carried out after 8 weeks of follow-up period. After the BDC, one girl was excluded from the study due to many diseases yielding 19 participants for data analysis. The girls were randomly divided into two groups: the control group $(\mathrm{CG} ; \mathrm{N}=8)$ and the experimental group $(\mathrm{EG} ; \mathrm{N}=11)$, see Table 1. 
Table 1: Anthropometric data of our sample of participants.

\begin{tabular}{|l|c|c|c|c|}
\hline & All & $\begin{array}{c}\text { Control } \\
\text { group }\end{array}$ & $\begin{array}{c}\text { Experimental } \\
\text { group }\end{array}$ & P \\
\hline $\mathbf{N}$ & $\mathbf{1 9}$ & $\mathbf{8}$ & $\mathbf{1 1}$ & \\
\hline Age / years & $16.4 \pm .9$ & $16.1 \pm .8$ & $16.6 \pm .9$ & .326 \\
\hline Body height / cm & $163.7 \pm 4.6$ & $166.6 \pm 2.3$ & $161.6 \pm 4.8$ & $.014^{*}$ \\
\hline Body mass / kg & $57.9 \pm 6.9$ & $58.0 \pm 6.3$ & $57.4 \pm 7.6$ & .735 \\
\hline Body mass index / m/kg & $21.6 \pm 2.3$ & $21.1 \pm 2.2$ & $22.0 \pm 2.4$ & .427 \\
\hline Fat mass / \% & $25.5 \pm 5.5$ & $23.9 \pm 5.4$ & $26.6 \pm 5.5$ & .313 \\
\hline Muscle mass / kg & $19.0 \pm 1.3$ & $19.6 \pm .8$ & $18.6 \pm 1.5$ & .116 \\
\hline
\end{tabular}

$*=$ significant differences between $\mathrm{CG}$ and $\mathrm{EG}$ at $\mathrm{p}<.05$.

\section{Exercise intervention in CG}

After BDC, the active CG performed 8 weeks of supervised physical exercise 3 times per week. The participants warmed up with 6 minutes of jogging and 4 minutes of whole-body stretching. After the warm up, participants performed one leg (non-dominant) hip raise when lying on the floor for exercising BF. The subjects were lying on the back, while non-dominant leg was in knee flexion at angle of about 30 degrees with heel placed on the floor. The dominant leg was suspended in the air. The upper legs were parallel in the width of the hips. The arms were crossed on the chest. Hip raise was performed until the line shoulder-hip-knee was aligned for 3 seconds. Then they lowered their hip to the original position in which they waited and relaxed for $17 \mathrm{~s}$. The participants performed 36 repetitions, with the intention to equalize the number of the contractions with EG. The exercise progressiveness was achieved with lifting heel support and with additional loads placed on the hips. They started exercising with body weight and a foot on the ground. Then we increased the support of the heel for $35 \mathrm{~cm}$. After that we added $2.5 \mathrm{~kg}$, then $5 \mathrm{~kg}$, followed by $7.5 \mathrm{~kg}$ and at the end $10 \mathrm{~kg}$ on the hips. Out of all $\mathrm{CG}$, only two girls increased the loading up to $10 \mathrm{~kg}$, others got up to $7.5 \mathrm{~kg}$.

\section{EMS Intervention in EG}

The girls in EG conducted one EMS training session a week before the BDC for familiarization. After the BDC, they performed EMS training for 8 weeks, 3 times per week. The EMS session consisted of 13 minutes of isometric EMS of knee extensors 
(vasti muscles at the same time) and 13 minutes of isometric EMS of knee flexors (BF). For EMS, we used two Cefar Rehab x2 electrical stimulators (CefarCompex, Scandinavia $\mathrm{AB}$ ). Before the EMS, the participants warmed up with 6 minutes of jogging and 4 minutes of stretching the whole body. Then we placed 6 self-adhesive electrodes on subject's thighs. Four positive electrodes, one-wire, were in the size of $5 \times 5 \mathrm{~cm}$ while two negative electrodes, two-wire, were in the size of $5 \times 10 \mathrm{~cm}$. All electrodes were from Dura-Stick plus, Cefar Compex, DJO brands. In the case of BF, the negative electrode was placed on the posterior side of the thigh just below the muscle gluteus maximus (GM) while the positive electrodes were placed as close as possible to the motor point of $\mathrm{m}$. semimembranosus and BF. On the front side of the thigh, we positioned the positive electrodes as close as possible to the motor points of VL and VM or on their muscular belly. The negative electrode was placed on the femoral triangle or 1-3 $\mathrm{cm}$ below the inguinal ligament. During the stimulation of VL and VM, the participants were sitting on a machine for knee extension or on the chair. During the knee extension, the stimulated leg was fixed in isometric position. Among the EMS session of BF, the subjects were lying on the abdomen and had a non-dominant leg stretched out, again rested and fixed in isometric position. All the exercises were carried out isometrically. EMS parameters were: a biphasic electric impulse with a pulse length of $400 \mu$ s and a frequency of $100 \mathrm{~Hz}, 1 \mathrm{~s}$ of rise up, $3 \mathrm{~s}$ of muscle contraction, $5 \mathrm{~s}$ of fall time and 17 s of pause with $8 \mathrm{~Hz}$ pulse currents. During the EMS session, each subject performed 36 repetitions of knee extension and 36 repetitions of knee flexion. The intensity level of the EMS was for each session the highest, according to the pain threshold and as a maximum tolerated level of each individual.

\section{Measurements}

Firstly, we measured the participants' body height and weight with standard tools from which we calculated body mass index. For determination of body composition, we performed bioelectric impedance analysis (Maltron Bioscan 916s, UK). Before measurement, the participants had to lay down on the measuring table for 30 minutes and then we placed two self-adhesive electrodes on the palm and two on the foot. We collected fat mass (FM, \%) and muscle mass (MM, kg) data for further analysis.

\section{Tensiomyography}

We measured maximal TMG response in all observed muscles. Firstly, we examined VL and VM where the participants were lying supine with knee flexed at 30 degrees ( 0 degrees represents fully extended joint. Afterwards, we measured BF where the participants were prone. For each muscle two surface self-adhesive electrodes were placed on the measured muscle at a distance of $5 \mathrm{~cm}$ proximally and distally from the sensor (Digital-optical comparator, TMG-BMC Ltd, Slovenia). The electrodes were 
connected to an electric stimulator (TMG-BMC Ltd., Slovenia). The sensor was positioned perpendicularly to the tangential plane of the measuring point. Measuring point was determined by a skilled expert, where the response reaches largest response. The stimulation impulse (monophasic rectangular electrical stimulus of 1 millisecond) was gradually increased from threshold to maximal amplitude. In each muscle we recorded two maximal twitch responses. From both, contraction time (Tc) and maximal amplitude $(\mathrm{Dm})$ were extracted. Tc was defined as the time when muscle contracted from $10 \% \mathrm{Dm}$ to $90 \% \mathrm{Dm}$. An average of was taken for further analysis.

\section{Isometric Dynamometry}

We measured unilateral maximal voluntary isometric contraction (MVC) and rate of force development (RFD) of knee flexors and extensors. The order of MVC and RFD measurement was as follows: MVC of right knee extensors, right knee flexors, left knee extensors and left knee flexors. Firstly, we placed the participants sited in knee dynamometer (S2P, Science to Practice, Ltd., Slovenia). The participant's femur epicondyle was in line with the dynamometer axis of rotation. The participants were firmly attached through the chest and hip with a belt. Distal part of the tibia was attached firmly to strength gauge. For measuring MVC and RFD, the knee angle was set at $60^{\circ}$ and $30^{\circ}$ for knee extensors and flexors, respectively. When measuring knee flexor, we added another belt to fix the upper leg. Prior to each measurement, a special warming-up was carried out. Warming-up included two submaximal isometric contractions at $50 \%$ and $70 \%$ of MVC and one at 100\% MVC. The pause between repetitions was $60 \mathrm{~s}$. Each isometric contraction lasted $5 \mathrm{~s}$, so that participants could escalate force in $2 \mathrm{~s}$ and retain force at $50 \%, 70 \%$ or $100 \% \mathrm{MVC}$ for $3 \mathrm{~s}$. Afterwards, we performed the main measurements. Even in the main measurements, the contraction time lasted 5 $\mathrm{s}$ as in the case of warming up (" $1,2,3$, hold, hold, hold, release": total $5 \mathrm{~s}$ ). The pause between the individual measurements was $60 \mathrm{~s}$. After the MVC measurements, we continued with RFD measurements in the same order. In this measurement, special warming included just one measurement in which the participants on the sign "now" had to develop greatest maximal force in the shortest possible time and hold the force for $2-3$ $\mathrm{s}$ and then release the muscle. The main measurement was followed by three measurements of maximal RFD in each position. The procedure was the same as in the warming up. The pause between individual measurements was $60 \mathrm{~s}$. The signals were captured and stored using a dynamometric ARS program "Analysis and Reporting Software for Dynamometers" (S2P, Science to Practice, Ltd., Slovenia). We took maximal MVC amplitude $(\mathrm{Nm})$ and $\mathrm{RFD}_{50}$ in first $50 \mathrm{~ms}(\mathrm{Nm} / \mathrm{s})$ for further analysis. 


\section{Statistical Analysis}

Mean values and standard deviations $( \pm \mathrm{SD})$ were calculated for all dependant variables. All variables pass normality and homogeneity tests (Shapiro-Wilk, Q-Q plot, visual inspection, Leven test). A repeated measures general linear model was used to assess the interaction between EG and $\mathrm{CG}$ with time in each dependent variable. If significant interactions were confirmed, we performed One-way ANOVA using Bonferroni correction to identify specific effects. When reporting specific effect, we presented partial eta squared for presenting effect size. The level of significance was established at $\mathrm{P}<.10$ for all decisions. Statistical analyses were performed using Statistical Product and Service Solutions (IBM SPSS Statistics 22, USA).

\section{RESULTS}

The participants have done 22 to 24 trainings (average $23.4 \pm .7$ trainings), yielding $97.5 \%$ adherence to the training programme. There were no differences between the two groups at the beginning of the study in the dependant variables except participants' body height. We did not observe and report any discomfort or injuries during and after the training program. The study protocol was carried out with no modifications.

In Table 2 we reported time effects in MVC of knee extensors $\left(\mathrm{P}=.019 ; \eta^{2}=.213\right)$ and knee flexors $\left(\mathrm{P}=.019 ; \eta^{2}=.209\right)$ as well as in $\mathrm{RFD}_{50}$ of knee extensors $(\mathrm{P}=.023$; $\left.\eta^{2}=.200\right)$. Time $x$ Group interactions were found in $\operatorname{MVC}\left(\mathrm{P}=.044 ; \eta^{2}=.172\right)$ and $\mathrm{RFD}_{50}$ $\left(\mathrm{P}=.046 ; \eta^{2}=.166\right)$ of knee extensors. Post hoc revealed increases in MVC of knee extensors in EG but not in $\mathrm{CG}$ at END $(\mathrm{P}=.085)$. Similarly, $\mathrm{RFD}_{50}$ of knee extensors increased in $\mathrm{EG}$, not in $\mathrm{CG}$, at $\mathrm{END}(\mathrm{P}=.049)$ and remained increased at $\mathrm{FU}(\mathrm{P}=.090)$. 
Sara PREGELJ, Boštjan ŠIMUNIČ: EFFECTS OF 8-WEEK ELECTRICAL MUSCLE STIMULATION ..., 105-120

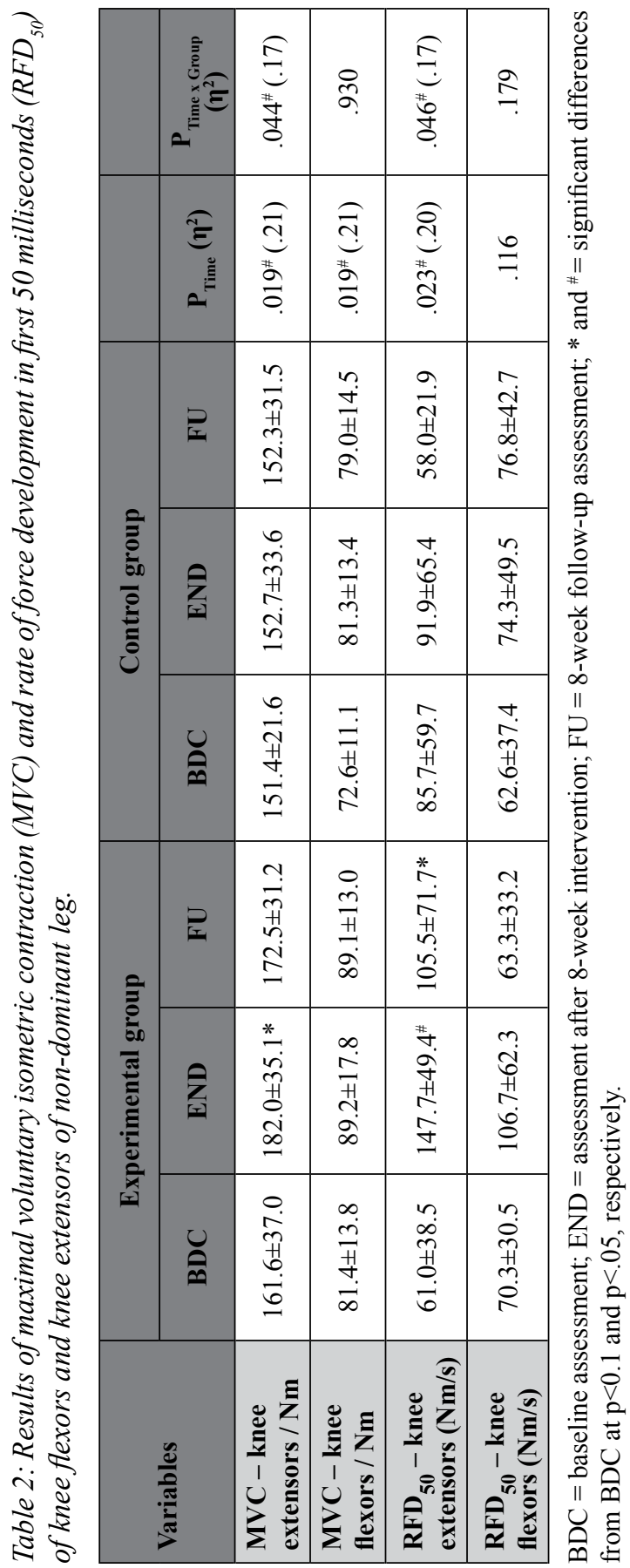


Table 3 reports the results obtained with tensiomyography, namely contraction time and maximal amplitude of biceps femoris and vasti muscles. We found Time x Group interaction effect only in $\operatorname{VM~Dm}\left(\mathrm{P}=.040 ; \eta^{2}=.185\right)$ and post-hoc analysis of individual relative changes revealed lower Dm in $\mathrm{EG}$ for $13.2 \%(\mathrm{P}=.011)$ at $\mathrm{END}$.

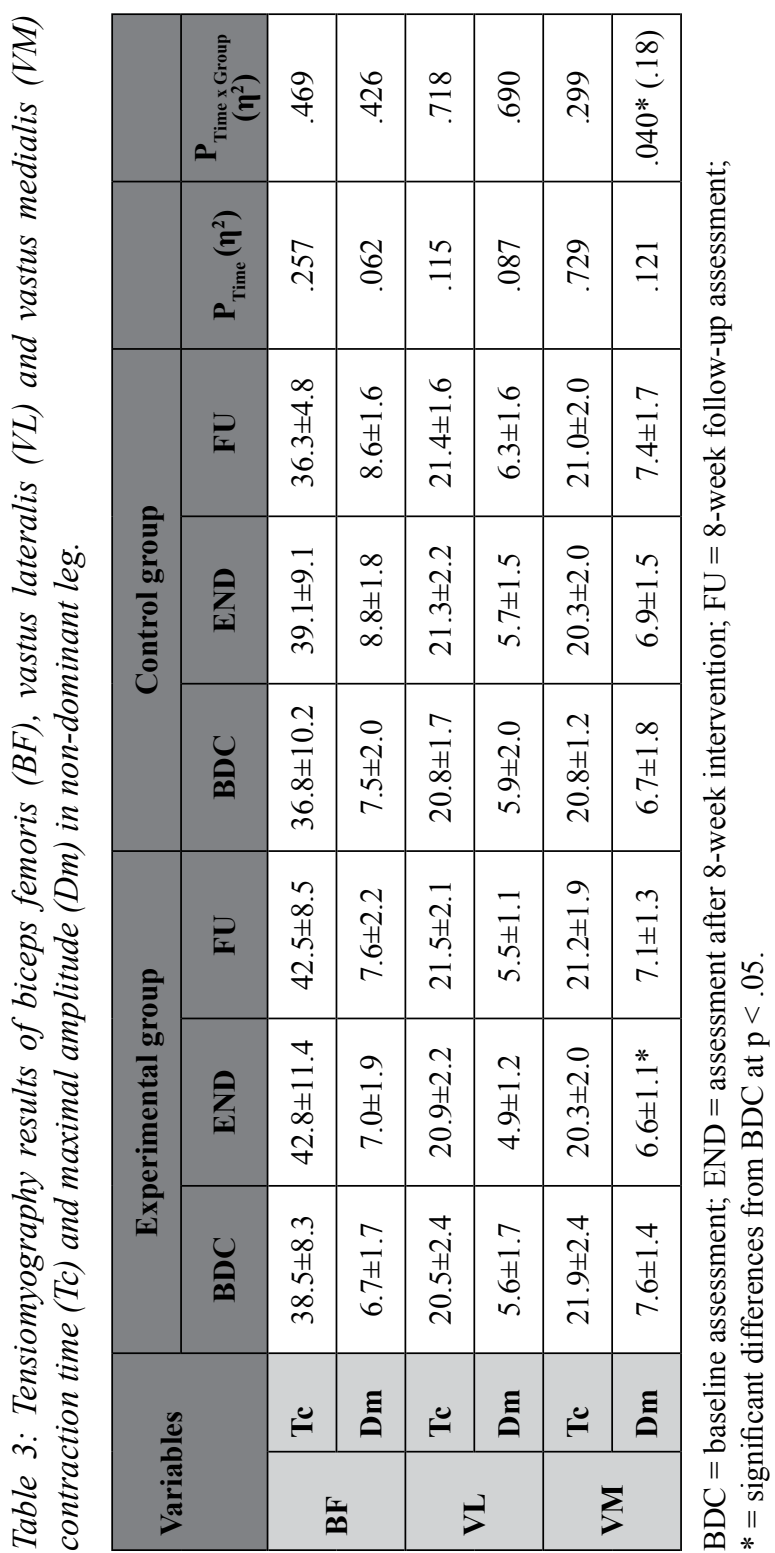




\section{DISCUSSION}

We found increased MVC strength (12.6\%) and RFD $_{50}(142.1 \%)$ of knee extensors after 8 week of EMS training in EG but not in an active CG. Furthermore, we noticed increased $\mathrm{RFD}_{50}$ of knee extensors also after 8-week follow-up (73\%). Increased isometric strength was also determined in previous studies; however, increments were higher due to passive CG and even shorter EMS training periods. Selkowitz (1985) reported $44 \%$ increased MVC strength in quadriceps after only 4 weeks of EMS, Stefanovska and Vodovnik (1985) reported 13.2 to $25.3 \%$ increased MVC strength of knee extensors by $25.3 \%$ after 3 weeks of EMS training, Lai, De Domenico, and Strauss, (1988) reported $48.5 \%$ and $24.2 \%$ increments in MVC strength of quadriceps after 3 weeks of high intensity and low intensity EMS training, respectively, with decreased but sustained (24.8 and $12.8 \%$, respectively) effects after the 3-week follow-up period. The study of Maffiuletti, Dugnani, Folz, Di Pierno, and Mauro, (2002) performed in athletes (volleyball players) reported comparable MVC strength gains after 4 weeks of combination of plyometric and EMS training (28.5\%). However, Herrero, Izquierdo, Maffiuletti, and Garcia-Lopez (2005) demonstrated in athletes that the combination of 4-week plyometric and EMS training demonstrated superior effects on quadriceps MVC strength (16.3\%) vs. EMS training (9.1\%) and that is comparable to the findings of our study. Similar results were demonstrated also by Billot, Martin, Paizis, Cometti, and Babault, (2010) that showed a $16.3 \%$ increase in MVC strength of quadriceps in footballers after 3 weeks of EMS training. Our study implemented a longer EMS training period, being 8 weeks, in young female athletes and with an active control group making direct comparison to other studies impossible. Gains of $12.6 \%$ from baseline and $19.2 \%$ from active $\mathrm{CG}$ at the end of the training period are somehow lower that those reported by others. Surely this must be attributed to the population studied and an active CG that was equalised to EG by the number of muscle contractions.

The mechanisms of MVC improvements after EMS were found on nervous and muscle levels. Gondin et al. (2005) reported increased muscular activation, anatomical cross-sectional area and pennation angle after 8-week EMS. In addition, they also reported nerve adaptations to occur within the first four weeks of EMS, while changes in muscle cross sectional area and pennation angle after 8-weeks of EMS. It seems that changes at the muscle level (e.g. hypertrophy, architecture) occur after 5 weeks of intense EMS training (Herrero et al., 2005; Maffiuletti, Dugnani, Folz, Di Pierno, \& Mauro, 2002). Therefore, the MVC gains obtained after EMS training could be attributed to muscular and neural adaptations, at least for monoarticular muscles (Gondin et al., 2005).

Based on the results of TMG, an indirect measure of myosin heavy chain composition (Šimunič et al., 2011) and atrophy (Pišot et al., 2008), we could conclude that there were no changes found in muscle composition (Tc remained unaltered) but there was smaller Dm found in VM without sustained effects at the follow-up. Since increases of Dm were already correlated to muscle atrophy after 35 days of bed rest (Pišot et al., 2008; Šimunič et al., 2008), the opposite, decreases of Dm were found after high-inten- 
sity plyometric exercise (Zubac \& Šimunič, 2016). Both aforementioned bed rest studies (Pišot et al., 2008; Šimunič et al., 2008) also investigated hypertrophy after bed rest, and during the recovery period that followed bed rest when Dm returned to baseline values. Decreases in Dm after plyometric training were paralleled to increases of muscle stiffness (Spurrs, Murphy, \& Watsford, 2003), which has a marginal effect on the capacity of skeletal muscle to effectively utilize elastic energy (Avela \& Komi, 1998) and movement efficacy (Pellegrino, Ruby, \& Dumke, 2016). There are many possible mechanisms that could affect Dm, a measure of muscle belly stiffness. Presumably, alterations in muscle stiffness could be modulated via changes in the visco-elastic properties of intramuscular and tendon connective tissue (Pišot et al., 2008). Alterations of pennation angle following bed rest, training, etc. might impact Dm either way, depending on the new initial sarcomere length, due to an increase in the fascicle length and / or more direct muscle fibre thickening and oscillation transfer in the transversal plane (to the TMG sensor) of muscle contraction. On the other hand, Fouré, Nordez, McNair, and Cornu (2011) demonstrated no change in muscle architecture in response to 14 weeks of plyometric training; however, they did note an increase in the passive series elastic component and a decrease in the active series elastic component. A decrease in the active SEC (mainly in the intrinsic mechanical properties of the muscle fibres) could occur due to a fibre-type transition phenomenon (Potteiger et al., 1999); however, this was not found in our study. Therefore, the Dm decrease must be linked to the passive series elastic component, which increases after high-intensity training (Burgess, Connick, Graham-Smith, \& Pearson, 2007; Fouré et al., 2011) and as well after the EMS (Da-Haeng, Jae-Keun, \& Joon-Hee, 2015).

Only two studies reported the RFD after EMS (Schmithusen, 2008; Speicher \& Kleinoder, 2009). After 4 weeks of EMS isometric training for the upper part of the body, Schmithusen (2008) reported $58 \%$ increase of RFD and a $20 \%$ increase in the force impulse $(<200 \mathrm{~ms})$. Speicher and Kleinoder (2009), reported a similar, $16 \%$ increase of force impulse ( $<200 \mathrm{~ms})$ after 4 weeks of EMS in lower part of the body, without finding changes in the RFD. Our study was in line with findings of Schmithusen (2008) and we demonstrated increased RFD ( $<50 \mathrm{~ms})$ for $60.7 \%$ with sustained effects after the follow-up period. Shorter time interval of RFD makes these three studies difficult to compare. Most likely, the order of motor unit recruitment, that occurs after EMS training (Maffiuletti, 2010; Seyri \& Maffiuletti, 2011; Jubeau, Gondin, Sartorio, \& Maffiuletti, 2007), plays an important role in increasing the RFD. During EMS, training motor units are recruited non-selectively and randomly in terms of size, and not according to Henneman's size principle in voluntary contractions. Jubeau et al. (2007) and Maffiuletti (2010) have demonstrated that during electrically elicited contractions the contraction time is stable when muscle is recruited between 20 and $80 \%$ of contraction intensity. In addition, during EMS training / contractions, fast motor units are easier and more activated compared to voluntary training / contractions at submaximal intensity (Billot et al., 2010). Therefore, we suggest that EMS training caused alterations in recruitment order during short maximal contractions $\left(\mathrm{RFD}_{50}\right)$ that is reflected in higher $\mathrm{RFD}_{50}$ due to activation of fast motor units. 


\section{CONCLUSION}

The study confirmed the effectiveness of EMS on skeletal muscle contractile properties in young female athletes. After controlling with an active control group we have demonstrated higher MVC and $\mathrm{RFD}_{50}$ of knee extensors, with higher muscle tone in VM. While the effects returned to baseline values in $\mathrm{RFD}_{50}$, remained significant also after eight weeks of follow-up.

\section{REFERENCES}

Avela, J., \& Komi, P. V. (1998). Reduced stretch reflex sensitivity and muscle stiffness after long-lasting stretch-shortening cycle exercise in humans. European journal of applied physiology, 78(5), 403-410. doi: 10.1007/s004210050438 VIEW ITEM

Babault, N., Cometti, G. B., Pousson, M., \& Chatard, C. (2007). Effects of electromyostimulation training on muscle strength and power of elite rugby players. Journal of strength and conditioning association, 21(2), 431-437. doi: 10.1519/R-19365.1 VIEW ITEM

Benito-Martinez, E., Sanchez-Lara, A., Berdejo del Fresno, D., \& Martinez-Lopez, J. (2011). Effects of combined electrostimulation and plyometric training on vertical jump and speed tests. Journal of human sport and exercise, 6(4), 603-615. doi:10.4100/ jhse.2011.64.04 VIEW ITEM

Benito-Martinez, E., Martinez-Amat, A., Lara-Sanchez, A., Berdejo-del-Fresno, D., \& Martinez-Lopez, E. (2013). Effect of combined electrostimulation and plyometric training on 30 meters dash and triple jump. Journal of sports medicine and physical fitness, 53(4), 387-395. VIEW ITEM

Billot, M., Martin, A., Paizis, C., Cometti, C., \& Babault, N. (2010). Effects of an electrostimulation training program on strength, jumping and kicking capacities in soccer players. Journal of strength and conditioning research, 24(5), 1407-1413. doi: 10.1519/ JSC.0b013e3181d43790 VIEW ITEM

Brocherie, F., Babault, N., Cometti, G., Maffiuletti, N., \& Chatard, J. (2005). Electrostimulation training effects on the physical performance of ice hockey players. Medicine and science in sports and exercise, 37(3), 455-460. doi: 10.1249/01. MSS.0000155396.51293.9F VIEW ITEM

Burgess, K. E., Connick, M. J., Graham-Smith, P., \& Pearson, S. J. (2007). Plyometric vs. isometric training influences on tendon properties and muscle output. Journal of strength and conditioning research, 21(3), 986-989. doi: 10.1519/R-20235.1 VIEW ITEM

Da-Haeng, K., Jae-Keun, J., \& Joon-Hee, L. (2015). Effects of low-frequency electrical stimulation on cumulative fatigue and muscle tone of the erector spinae. Journal of physical therapy science, 27(1), 105-108. doi: 10.1589/jpts.27.105 VIEW ITEM

Deley, G., Cometti, C., Fatnassi, A., Paizis, C., \& Babault, N. (2011). Effects of combined electromyostimulation and gymnastics training in prepubertal girls. The journal of strength and conditioning research, 25(2), 520-526. doi: 10.1519/JSC.0b013e3181 bac451 VIEW ITEM 
Đokić, Z., \& Međedović, B. (2013). Electrical muscle stimulation (ems) implementation in explosive strength development. Crnogorska sportska akademija "Sport Mont”, XI(3738-39), 207-211.

Enoka, R. (1988). Muscle strength and its development. Sports medicine, 6(3), 146-168. doi: 10.2165/00007256-198806030-00003 VIEW ITEM

Fouré, A., Nordez, A., McNair, P., \& Cornu, C. (2011). Effects of plyometric training on both active and passive parts of the plantarflexors series elastic component stiffness of muscle-tendon complex. European journal of applied physiology, 111(3), 539-548. doi: 10.1007/s00421-010-1667-4 VIEW ITEM

Gondin, J., Guette, B., \& Martin, A. (2005). Electromyostimulation training effects on neural drive and muscle architecture. Medicine and science in sports and exercise, 37(8), 1291-1299. doi: 10.1249/01.mss.0000175090.49048.41 VIEW ITEM

Gregory, M. C. \& Bickel, C. S. (2005). Recruitment patterns in human skeletal muscle during electrical stimulation. Physical therapy, 85(4), 358-364. doi: 10.1093/ptj/85.4.358 VIEW ITEM

Henneman, E., Somjen, G. \& Carpenter, D. O. (1965). Functional significance of cell size in spinal motoneurons. Journal of neurophysiology, 28(3), 560-580. doi: 10.1152/ jn.1965.28.3.560 VIEW ITEM

Herrero, J., Izquierdo, M., Maffiuletti, N., \& Garcia-Lopez, J. (2005). Electromyostimulation and plyometric training effects on jumping and sprint time. International journal of sports medicine, 27(7), 533-539. doi: 10.1055/s-2005-865845 VIEW ITEM

Jubeau, M., Gondin, J., Sartorio, A., \& Maffiuletti, N. (2007). Random motor unit activation by electrostimulation. International journal of sports medicine, 28(11), 901-904. doi: 10.1055/s-2007-965075 VIEW ITEM

Lai, H., De Domenico, G., \& Strauss, R. G. (1988). The effect of different electro-motor stimulation training intensities on strength improvement. The Australian journal of physiotherapy, 34(3), 151-164. doi: 10.1016/S0004-9514(14)60607-3 VIEW ITEM

Lategan, L., Crafford, K., Suliman, F., \& Govender, N. (2014). Electrical muscle stimulation (EMS) training of the hamstrings. African journal for Physical, Health education, Recreation and Dance, 20(21), 439-452. VIEW ITEM

Maffiuletti, N., Cometti, G., Amiridis, I., Martin, A., Pousson, M., \& Chatard, J. (2000). The effects of electromyostimulation training and basketball practice on muscle strength and jumping ability. International journal of sports medicine, 21(6), 437-443. doi: 10.1055/s-2000-3837 VIEW ITEM

Maffiuletti, N., Dugnani, S., Folz, M., Di Pierno, E., \& Mauro, F. (2002). Effect of combined electrostimulation and plyometric training on vertical jump height. Medical and Science in Sports and Exercise, 34(10), 1638-1644. doi: 10.1097/00005768-20021000000016 VIEW ITEM

Maffiuletti, N., Pensini, M., \& Martin, A. (2002). Activation of human plantar flexor muscles increases after electromyostimulation training. Journal of applied physiology, 92(4), 1383-1392. doi: 10.1152/japplphysiol.00884.2001 VIEW ITEM

Maffiuletti, N., Bramanti, J., Jubeau, M., Bizzini, M., Deley, G., \& Cometti, G. (2009). Feasibility and efficacy progressive electrostimulation strength training for competitive tennis players. Journal of strength and conditioning research, 23(2), 677-682. doi: 10.1519/JSC.0b013e318196b784 VIEW ITEM 
Maffiuletti, N. (2010). Physiological and methodological considerations for the use of neuromuscular electrical stimulation. European journal of applied physiology, 110(2), 223234. doi: 10.1007/s00421-010-1502-y VIEW ITEM

Malatesta, D., Cattaneo, F., Dugnani, S., \& Maffiuletti, N. (2003). Effects of electromyostimulation training and volleyball practice on jumping ability. Journal of strength conditioning research, 17(3), 573-579. VIEW ITEM

Marqueste, T., Messan, F., Hug, F., Laurin, J., Dousset, E., Grelot, L., \& Decherchi, P. (2010). Effect of repetitive biphasic muscle electrostimulation training on vertical jump performances in female volleyball players. International journal of sport and health science, 8, 50-55. doi: 10.5432/ijshs.20090019 VIEW ITEM

Martinez-Lopez, E., Benito-Martinez, E., Hita-Contreras, F., Lara-Sanchez, A., \& Martinez-Amat, A. (2012). Effects of electrostimulation and plyometric training program combination on jump height in teenage athletes. Journal of sports science and medicine, 11(4), 727-735. VIEW ITEM

Pellegrino, J., Ruby, B. C., \& Dumke, C. L (2016). Effect of plyometrics on the energy cost of running and MHC and Titin isoforms. Medicine \& Science in Sports \& Exercise, 48(1), 49-56. doi: 10.1249/MSS.0000000000000747 VIEW ITEM

Pichon, F. C., Martin, A., \& Cometti, G. (1995). Electrical stimulation and swimming performance. Medicine \& science in sports \& exercise, 27(12), 1671-1676. doi: 10.1249/00005768-199512000-00014 VIEW ITEM

Potteiger, J. A., Lockwood, R. H., Haub, M. D., Dolezal, B. A., Almuzaini, K. S., Schroeder, J. M., Zebas, C. J. (1999). Muscle power and fiber characteristics following 8 weeks of plyometric training. Journal of strength and conditioning research, 13(3), 275-279. doi: 10.1519/00124278-199908000-00016 VIEW ITEM

Pišot, R., Narici, M., Šimunič, B., De Boer, M., D., Seynnes, O., Jurdana, M., ... Mekjavić, I., B. (2008). Whole muscle contractile parameters and thickness loss during 35-day bed rest. European journal of applied physiology, 104(2), 409-414. doi: 10.1007/ s00421-008-0698-6 VIEW ITEM

Sariyildiz, A. M., Rezvani, A., \& Karacan, I. (2011). Cross-education of muscle strength: cross-training effects are not confined to untrained contralateral homologous muscle. Scandinavian journal of medicine and science in sports, 21(6), 359-364. doi: 10.1111/j.1600-0838.2011.01311.x VIEW ITEM

Selkowitz, M. (1985). Improvement in isometric strength of the quadriceps femoris muscle after training with electrical stimulation. Journal of the American physical therapy association, 65(2), 186-196. doi: 10.1093/ptj/65.2.186 VIEW ITEM

Seyri, M., \& Maffiuletti, A. (2011). Effect of electromyostimulation training on muscle strength and sport performance. Strength and conditioning journal, 33(1), 70-75. doi: 10.1519/SSC.0b013e3182079f11 VIEW ITEM

Singer, K. (1986). The influence of unilateral electrical muscle stimulation on motor unit activity patterns in atrophic human quadriceps. The Australian journal of physiotherapy, 32(1), 31-37. doi: 10.1016/S0004-9514(14)60641-3 VIEW ITEM

Schmithusen, J. (2008). Vergleich der auswirkungen eines ganzkorper-elektrostimulationstrainings, eines traditionellen krafttrainings undderen kombination auf isometrische und dynamische kraftparameter. Diplomarbeit, Deutsche Sporthochschule Köln, Köln.

Speicher, U., \& Kleinoder, H. (2009). Effektivitatsprufung klassischer und moderner Krafttrainingsverfahren: differentielle Kraftdiagnostik und moderne trainings Regulation. Forschung Innovat Tech Wissenschftsmagazin, 14(1), 20-22. 
Spurrs, R. W., Murphy, A. J., \& Watsford, M. L. (2003). The effect of plyometric training on distance running performance. European journal of applied physiology, 89(1), 1-7. doi: 10.1007/s00421-002-0741-y VIEW ITEM

Stefanovska, A., \& Vodovnik, L. (1985). Change in muscle force following electrical stimulation. Scandinavian journal of medicine, 17(3), 141-146.

Šimunič, B., Degens, H., Rittweger, J., Narici, M., Mekjavić, I., B., \& Pišot, R. (2011). Noninvasive estimation of myosin heavy chain composition in human skeletal muscle. Medicine and science in sports and exercise, 43(9), 1619-1625. doi: 10.1249/ MSS.0b013e31821522d0 VIEW ITEM

Šimunič, B., Rittweger, J., Cankar, G., Jurdana, M., Volmut, T., Šetina, T., ... Pišot, R. (2008). Odziv sestave telesa, mišične togosti in ravnotežja po 35-dnevni odsotnosti gibanja pri mladih in zdravih preiskovancih [Changes in body composition, muscle stiffness and postural stability occurring in healthy young men submitted to a 35-day bed rest]. Zdravstveno varstvo, 47(2), 60-71.

Zubac, D. \& Šimunič, B. (2016). Skeletal muscle contraction time and tone decrease after 8 weeks of plyometric training. Journal of strength and conditioning research, 31(6), 1610-1619. doi: 10.1519/JSC.0000000000001626 VIEW ITEM

Zhou, S., Oakman, A., \& Davie A., J. (2002). Effects of unilateral voluntary and electromyostimulation training on muscular strength on the contralateral limb. Hong Kong Journal of sports medicine and sports science, XIV, 1-11. 